Proc. Estonian Acad. Sci. Biol. Ecol., 2003, 52, 1, 26-39

\title{
Autumn numbers and distribution of the staging greylag goose Anser anser in Estonia in 1990-98
}

\author{
Aivar Leito $^{\mathrm{a}^{*}}$, Tõnu Möls ${ }^{\mathrm{b}}$, Eve Mägi ${ }^{\mathrm{c}}$, and Taivo Kastepõld ${ }^{\mathrm{c}}$ \\ ${ }^{a}$ Environmental Protection Institute, Estonian Agricultural University, Akadeemia 4, 51003 Tartu, \\ Estonia \\ b Institute of Zoology and Botany, Estonian Agricultural University, Riia 181, 51014 Tartu, \\ Estonia; tonumols@ut.ee \\ c Matsalu Nature Reserve, Penijõe, 90305 Lihula, Läänemaa, Estonia; eve@matsalu.ee, \\ matsalu@matsalu.ee
}

Received 14 March 2002, in revised form 29 July 2002

\begin{abstract}
We analysed the results of mid-September counts of staging greylag geese in Estonia in 1990-98. Each year 9800 to 15700 greylags were counted in western Estonia during this period. The analysis provides no evidence of an overall linear trend, but differences between linear trends in certain site clusters are statistically significant proving that the preferences in halting sites have changed in the study years. Principal Component Analysis suggests that the first principal component, characterizing the total number of birds and defined as the Abundance Factor, explains about 56\% of the variability of square-root transformed counts. The second principal component, Matsalu Preference Factor, indicates whether birds prefer Matsalu and South Saaremaa to Hiiumaa, West Saaremaa and East Saaremaa. It explains about $24 \%$ of the total variability. A significant increase of Matsalu Preference Factor suggests that the importance of Matsalu Bay has increased considerably among geese staging areas in recent years. Two structural indices describe stable proportions of the distribution of birds over the study area characterizing their possible relocation patterns.
\end{abstract}

Key words: Estonia, distribution, numbers, staging, relocation, Anser anser.

\section{INTRODUCTION}

Greylag goose Anser anser L. is a common breeding, moulting, and passage bird in Estonia. It is distributed mostly in western Estonia, which is one of the most important autumn-staging areas of the species (Madsen et al., 1999). Only a few breeding sites are known in northern Estonia. In other parts of the country it occurs occasionally.

The number of autumn staging greylag geese in Estonia depends on the size of the local population as well as on the number of birds coming from outside. The size of the local population was estimated to be 300 pairs in the 1930s (Kumari, 1938), 400 pairs

\footnotetext{
* Corresponding author, leito@envinst.ee
} 
in 1960, 500 pairs in 1964, 750 pairs in 1972 (Paakspuu, 1974), 800 pairs in 1982 (Kumari, 1984), up to 1200 pairs in the late 1980s, up to 1500 pairs at the beginning of the 1990s (Leibak et al., 1994; Leito, 1996a), and 1100-1200 pairs in the late 1990s (Lõhmus et al., 1999). Consequently, the number of breeding pairs increased steadily until the beginning of the 1990s and decreased slightly during the last decade.

According to the estimation of local breeding and non-breeding populations, the total number of autumn-staging greylag geese in Estonia was assessed to be from 7000 to 9000 in the 1990s. However, the counts in mid-September reflected that the actual number of geese in this period was 9800-15 700. This suggests that a significant number of birds are coming to Estonia from outside.

It is known that the majority (about 1100 pairs) of the Finnish breeding greylag goose population belong to the same Central European/North African biogeographical population as the Estonian population, using the same Central European flyway (Madsen et al., 1999). In late summer/early autumn, large flocks concentrate in southwestern Finland. At least 5000 greylags were counted on Kemiö Island (Madsen et al., 1999). A part of these birds migrate through and have stopovers in West Estonia. This has been confirmed by several observations of flocks of geese flying over the Gulf of Finland to Estonia, and also by re-sightings of banded Finnish birds in Estonia in late summer and in autumn. Unfortunately, we do not know the actual numbers and the proportion of the Finnish greylag staging in Estonia in September. A few birds may also originate from Leningrad Province in Russia, where a small population of greylag goose are breeding.

In general, estimating the number of staging birds is a difficult task. The number of birds remaining unobserved depends on the efficiency of local observers' work, weather conditions, synchronization of observations, and many other factors. The actual number of staging birds can only be estimated by using sophisticated statistical methods.

Until the publication of this article, only a few brief reports on autumn staging of the greylag goose in Estonia had been published (Leito, 1994, 1996a). Results of mid-September counts in Estonia were included also in the monographs Atlas of Anatidae Populations in Africa and Western Eurasia (Scott \& Rose, 1996) and Goose Populations of the Western Palearctic. A Review of Status and Distribution (Madsen et al., 1999) but there are no statistical analyses of census data.

The aim of the present study is to work out and test appropriate statistical methods for analysing the mid-September counts of geese in different staging sites and in Estonia as a whole. We analyse the annual trends and distribution of autumn staging greylag geese in Estonia in the period 1990-98 and the relative importance of various staging sites.

\section{MATERIAL AND METHODS}

\section{Study area and censuses}

The study was carried out in West Estonia in 1990-98 (Fig. 1). In different years censuses covered 85-95\% of all known important staging sites in Estonia. 


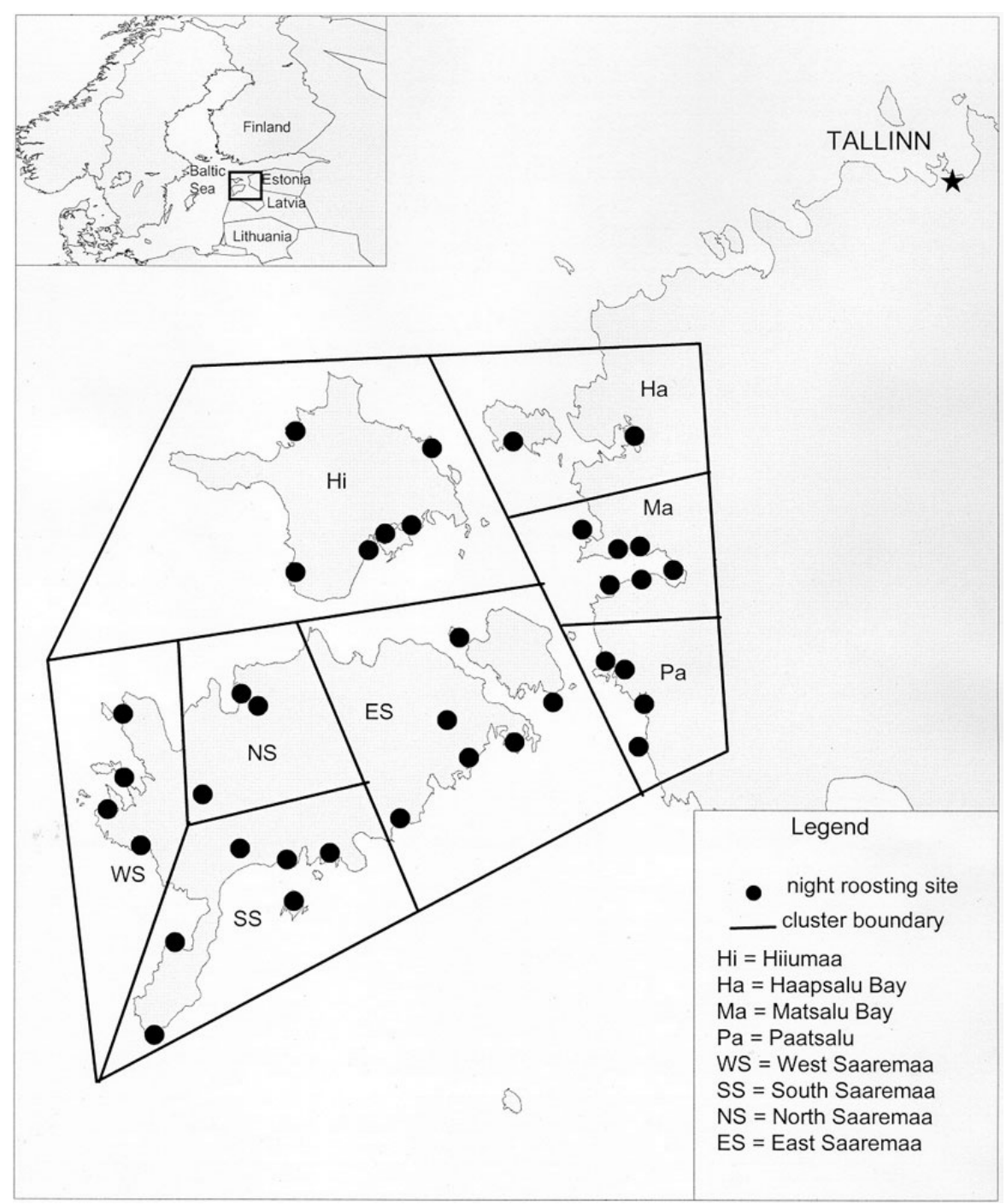

Fig. 1. Location of the study area. Staging sites and clusters of the greylag goose in West Estonia in September 1990-98.

Exceptionally, no censuses were conducted in Saaremaa in 1993. A total of 51 census sites were involved. All censuses were made during a period of two weeks in the middle of September, the majority between the 10th and the 24th.

As a rule, geese were counted at the time of their arrival at the roosting site in the evening. Censuses started at least two hours before sunset and finished one hour after sunset. If the roosting site was not known or if the visibility was too bad in the evening, the geese were also counted in their feeding areas in the daytime. The observers were professional ornithologists and employees of a nature reserve, as well as volunteers of local bird clubs and the Estonian Ornithological Society. 
An average of 30 to 50 people a year took part in censuses over the 1990-98 period, the observers being the same for the whole study period.

\section{Data preparation}

The main raw census data file has a high percentage of non-randomly missing values and underestimated bird counts. If all the 51 used observation sites had been followed during the nine-year study, $9 \times 51=459$ single counts would have been obtained. Instead, about $57 \%$ of count records are missing and some sites are represented with a very few observations. In 15 sites the rate of missing data exceeds $88 \%$.

In order to present a full multivariate data table, the count values for missing cells were derived from factual values by SAS/STAT/MIXED procedure (SAS Institute Inc., 1996) using a main-effect model with fixed factors 'year' and 'site'. For the purpose of normalizing the statistical distribution, the documented counts were square root transformed before the calculations. The prediction was repeated twice, first using the raw data only, and then, in the second iteration, the raw data together with the predicted values from the first iteration (after replacing a few negative predicted values with zeroes). The second iteration changed the data table only very slightly. The final $9 \times 51$ data table consists of raw documented values plus predicted values in the originally empty cells.

For the following statistical analysis, these 51 sites were grouped into eight clusters (Fig. 1) and the counts (real or predicted) in each cluster were summed up using natural scale (not the square root scale). As a result, the main table of 9 years $\times 8$ clusters was produced (Table 1 ). For convenience, this table also

Table 1. Estimated (upper row) and observed (lower row, in italic) bird counts in eight site clusters defined in Fig. 1. 0 - not observed

\begin{tabular}{|c|c|c|c|c|c|c|c|c|c|}
\hline Year & $\mathrm{Hi}$ & $\mathrm{Ha}$ & $\mathrm{Ma}$ & $\mathrm{Pa}$ & ES & SS & WS & $\mathrm{NS}$ & Total \\
\hline \multirow[t]{2}{*}{1990} & 3550 & 390 & 8159 & 951 & 2477 & 912 & 2017 & 528 & 18984 \\
\hline & 2776 & 23 & 6205 & 400 & 580 & 80 & 110 & 0 & 10174 \\
\hline \multirow[t]{2}{*}{1991} & 4488 & 659 & 11710 & 1450 & 3442 & 1397 & 3027 & 700 & 26873 \\
\hline & 3350 & 0 & 9550 & 0 & 130 & 691 & 700 & 430 & 14851 \\
\hline \multirow[t]{2}{*}{1992} & 2577 & 323 & 6133 & 790 & 1823 & 709 & 2751 & 387 & 15493 \\
\hline & 2000 & 0 & 4885 & 300 & 794 & 345 & 1500 & 0 & 9824 \\
\hline \multirow[t]{2}{*}{1993} & 4254 & 289 & 8410 & 921 & 2720 & 1237 & 2206 & 568 & 20605 \\
\hline & 3600 & 200 & 6490 & 160 & 0 & 0 & 0 & 0 & 10450 \\
\hline \multirow[t]{2}{*}{1994} & 2129 & 560 & 6361 & 928 & 4497 & 1002 & 2312 & 464 & 18253 \\
\hline & 1790 & 560 & 4730 & 0 & 3370 & 790 & 700 & 300 & 12240 \\
\hline \multirow[t]{2}{*}{1995} & 1438 & 1308 & 11191 & 1170 & 2668 & 1460 & 2752 & 1213 & 23200 \\
\hline & 700 & 1200 & 9200 & 0 & 650 & 1300 & 1620 & 1000 & 15670 \\
\hline \multirow[t]{2}{*}{1996} & 1095 & 155 & 7402 & 534 & 1525 & 1204 & 1229 & 285 & 13429 \\
\hline & 940 & 130 & 6385 & 0 & 770 & 1197 & 910 & 200 & 10532 \\
\hline \multirow[t]{2}{*}{1997} & 1274 & 244 & 8217 & 609 & 1621 & 1052 & 1408 & 260 & 14685 \\
\hline & 750 & 210 & 7079 & 154 & 240 & 920 & 650 & 260 & 10263 \\
\hline \multirow[t]{2}{*}{1998} & 1208 & 255 & 10643 & 780 & 2377 & 1502 & 1160 & 325 & 18250 \\
\hline & 710 & 200 & 9237 & 0 & 1164 & 1304 & 282 & 190 & 13087 \\
\hline $\begin{array}{l}\text { Mean of } \\
\text { estimated counts }\end{array}$ & 2445 & 465 & 8692 & 904 & 2572 & 1164 & 2096 & 526 & 18864 \\
\hline
\end{tabular}


contains the original raw data counts. On average, the documented numbers of birds constitute approximately $63 \%$ of the estimated numbers.

\section{Analysis}

Annual trends were tested with SAS/GLM procedure (SAS Inst. Inc., 1996). In this analysis, only square rooted raw data were used to circumvent confused statistical problems with predicted count values. We stayed at two models expressed in SAS programming language as

CLASS site cluster;

MODEL sqn = site year(cluster)/SS3;

and

CLASS site cluster;

MODEL sqn $=$ site year year*cluster/SS3.

Here the classification factors 'site' and 'cluster' had 51 and 8 levels respectively. The analysis variable sqn is square rooted count number. These models present different linear annual trends in different site clusters and perform Type 3 ANOVA suitable for unbalanced data like ours. Slopes for some selected sites were compared by CONTRAST and ESTIMATE options using a pair-wise comparison policy.

Statistical dependence between annual counts in eight site clusters was analysed with the Eigenvalue Analysis applied to the estimated counts. Two approaches were used here. First, the $8 \times 8$ correlation matrix of estimated counts from Table 1 was analysed with the SAS/PRINCOMP procedure. Two principal components were found to reflect changes in the total number of birds and the preferences for sites. Additionally, two structural indices corresponding to the least varying eigenvectors were established (cf. Möls \& Paal, 1998). These indices characterize the most stable relations between the numbers of birds in eight staging site clusters.

The other approach was developed in order to find out which of the site clusters share common groups of birds moving occasionally between those sites. The SAS/PRINCOMP procedure was applied to the covariance matrix, eliminating first the fluctuations of the total number of birds in the whole area. Site clusters having dominating loadings in a certain factor were considered as an "exchange system'. Isolated (or closed) exchange systems were defined by factors having only one major loading coefficient. In this way, seven exchange systems were outlined.

\section{RESULTS}

The analysis of long-term changes in bird counts based on models (1) and (2) is summarized in Table 2. There is no evidence of an overall linear trend in the 
Table 2. ANOVA results of the 196 square root transformed bird counts of 51 sites on the coast of West Estonia. Cluster notations as in Fig. 1

\begin{tabular}{l|c|r|c|c|c}
\hline \multicolumn{1}{c|}{ Factor } & Model & $\mathrm{df}_{1}$ & $\mathrm{df}_{2}$ & $F$-statistic & $P$-value \\
\hline Site & $(1),(2)$ & 50 & 137 & 2.27 & 0.0001 \\
Year & $(2)$ & 1 & 137 & 0.48 & 0.4881 \\
Year* Site cluster & $(2)$ & 7 & 137 & 2.62 & 0.0142 \\
Year(Site cluster) & $(1)$ & 8 & 137 & 2.55 & 0.0127 \\
MA compared to HI + WS + ES & $(1)$ & 1 & 137 & 7.56 & 0.0067 \\
The whole model & $(1),(2)$ & 58 & 137 & 3.34 & 0.0001
\end{tabular}

total number of birds having staged in western Estonia over the 1990-98 period $(P=0.488)$. On the other hand, differences between linear trends in different site clusters are significant $(P<0.015)$, suggesting that preferences for staging places have changed in the study years. For example, counts in the Matsalu (Ma) site cluster have increased compared to the mean counts in Hiiumaa (Hi), West Saaremaa (WS), and East Saaremaa (ES) $(P=0.0067)$. Consequently, the Matsalu site cluster has become more 'popular' among birds in recent years.

Estimated annual counts in different clusters exhibit synchronous fluctuations (Fig. 2); thus, multivariate analysis has to be used. Results of the Principal Component Analysis of the related correlation matrix, focusing on two principal components, are summarized in Table 3. The first principal component with positive and approximately equal loading coefficients is the most influential. This component expresses clearly the total number of birds in the study area and is therefore referred to as the Abundance Factor (AF). It explains about $56 \%$ of the

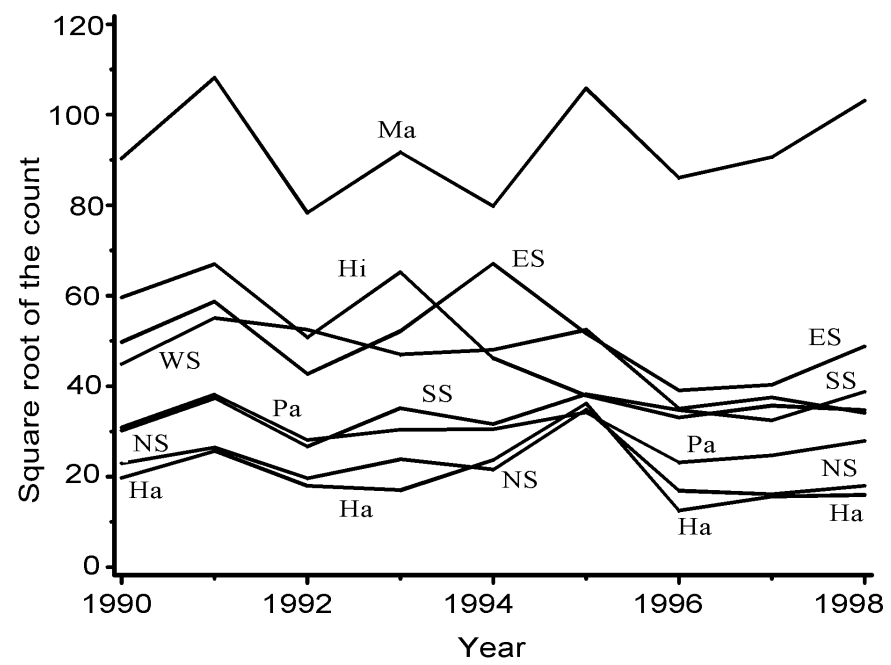

Fig. 2. Estimated annual counts of birds in eight site clusters. 
Table 3. Percentage of total variance, significance ( $P$-value) of the linear trend over years, and coefficients of the four abundance distribution characteristics

\begin{tabular}{l|c|c|c|c}
\hline & $\begin{array}{c}\text { Abundance } \\
\text { Factor }\end{array}$ & $\begin{array}{c}\text { Matsalu } \\
\text { Preference } \\
\text { Factor }\end{array}$ & $\begin{array}{c}\text { First } \\
\text { Structural } \\
\text { Index }\end{array}$ & $\begin{array}{c}\text { Second } \\
\text { Structural } \\
\text { Index }\end{array}$ \\
\hline Total variance, \% & 56 & 24 & 0.003 & 0.008 \\
$P$-value & 0.1944 & 0.0269 & 0.7816 & 0.5065 \\
Hiiumaa & 0.250 & -0.415 & 0.079 & -0.028 \\
Haapsalu & 0.415 & 0.073 & 0.699 & 0.039 \\
Matsalu & 0.283 & 0.515 & -0.022 & -0.091 \\
Paatsalu & 0.461 & -0.060 & -0.158 & 0.944 \\
East Saaremaa & 0.329 & -0.164 & -0.043 & -0.094 \\
South Saaremaa & 0.189 & 0.619 & 0.216 & 0.249 \\
West Saaremaa & 0.378 & -0.372 & -0.035 & -0.142 \\
North Saaremaa & 0.431 & 0.076 & -0.656 & -0.090
\end{tabular}

total variance of square-root transformed counts. Figure 3 demonstrates notable annual fluctuation of the AF value but the linear trend over years is not significant $(P=0.19)$. This is in good accordance with the results of Table 2, where the factor 'year' is not statistically significant. The highest numbers of birds were observed in 1991 and 1995, each time followed by a deep depression.

The second principal component explains about $24 \%$ of the total variability of bird counts. It can be interpreted as a factor of relocation of birds from Hiiumaa and West and East Saaremaa to South Saaremaa and Matsalu. This factor is defined as the Matsalu Preference Factor (MPF) because its value will increase if birds move to Matsalu, and also to South Saaremaa. MPF has increased during the

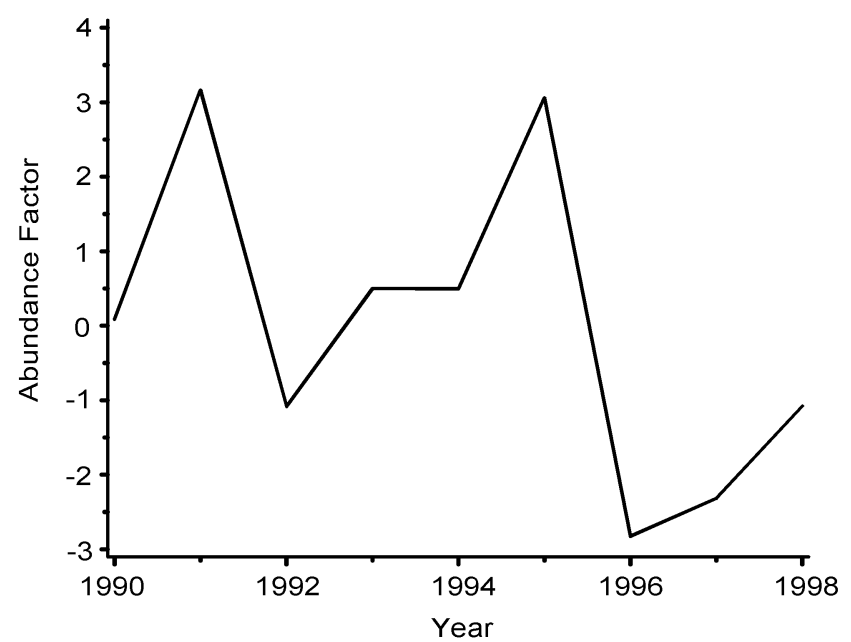

Fig. 3. Annual values of the Abundance Factor. The linear trend is not significant $(P=0.19)$. 


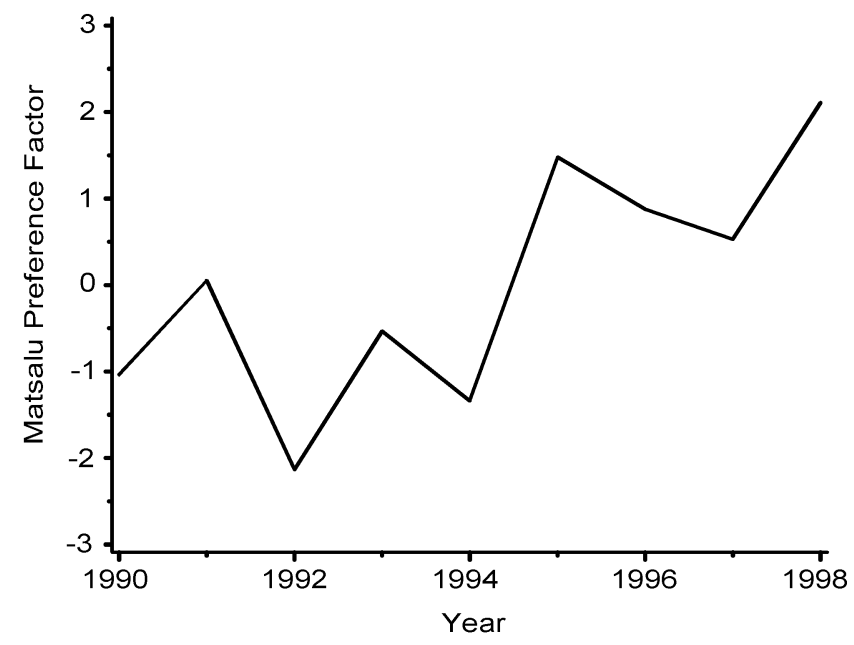

Fig. 4. Annual values of the Matsalu Preference Factor. There is a significant linear trend $(P=0.027)$ showing that at the end of the study period Matsalu and South Saaremaa became more attractive for greylag geese.

study $(P=0.027$, see Table 3), thus Matsalu and South Saaremaa have become more attractive as staging places. This result conforms with the ANOVA results presented in Table 2. Figure 4 illustrates the MPF tendency graphically. Note that if covariance is analysed instead of correlations, the increasing tendency of the value of MPF will be even more significant $(P=0.0023)$.

Proportionality of birds' distribution over the observation area was studied using structural indices (SI) based on Eigenvalue Analysis of the covariance matrix of natural (not square-rooted) counts in eight site clusters. Two SI of special interest were extracted. The first SI has a very low variance representing only $0.003 \%$ of the total variability (Table 3). Coefficients of this SI, after being multiplied by ten, give rise to the approximate equality

$0.8 \mathrm{DHi}+7 \mathrm{DHa}+2.2 \mathrm{DSS} \approx 0.2 \mathrm{DMa}+0.4 \mathrm{DES}+1.6 \mathrm{DPa}+0.3 \mathrm{DWS}+6.6 \mathrm{DNS}$

where DHi, ..., DNS denote changes in the bird numbers in the respective sites. A simple but rough interpretation of this equality is that annual fluctuations of bird numbers are synchronous in Haapsalu and North Saaremaa, and also in South Saaremaa and Paatsalu. Indeed, if the changes in Ha and NS are approximately equal, and so are the changes in SS and Pa, formula (3) will hold. Figure 2 confirms this interpretation, clearly demonstrating synchrony in bird counts. Note that as the coefficients of $\mathrm{Pa}$ and SS in formula (3) are smaller than those of Ha and NS, count fluctuations in $\mathrm{Ha}$ and NS are probably more synchronous than in $\mathrm{Pa}$ and SS. It can be hypothesized that an unsettled fraction of birds prefer the Ha-NS system while birds of the Pa-SS system are more determined and site-stable. 
In a similar way the second SI with $0.008 \%$ of the total count variability will lead to the equality

$$
\text { 9.4DPa + 2.4DSS + 0.4DHa } \approx 1.4 \mathrm{DWS}+0.9(\mathrm{DNS}+\mathrm{DMa}+\mathrm{DES})+0.2 \mathrm{DHi} .
$$

Here the coefficients of DPa and DSS are considerably higher than those of other sites. Hence, the corresponding count fluctuations must be smaller suggesting that the inhabitants of Pa and SS sites are more determined to occupy these sites.

The characteristics given in Table 3 depend on random annual fluctuations of the total number of birds in the study area. In order to estimate the mobility of birds between sites, the total count as a disturbing factor was eliminated ('partialled out') when performing the Principal Components Analysis. The results of this analysis are given in Table 4. Note that there is no AF analogue in Table 4 because the effect of the total count has been eliminated. For this reason, the F1 in Table 4 is an analogue of MPF.

On the basis of Table 4, the following exchange systems can be outlined (beginning with the most important factors):

1. The Hiiumaa-Matsalu system. If Matsalu is considered as an acceptor, East Saaremaa and West Saaremaa will serve, along with Hiiumaa, as donors.

2. The Hiiumaa-East Saaremaa system, with possible parallel connections between Matsalu and East Saaremaa.

3. The East Saaremaa-West Saaremaa system.

4. The North Saaremaa-West Saaremaa system.

5. The relatively closed South Saaremaa system.

6. The relatively closed Paatsalu system.

7. The Haapsalu-North Saaremaa system.

Among these hypothetical exchange systems, the Hiiumaa-Matsalu system seems to be the most authentic one. Figure 5 illustrates the dynamics of bird counts in this system. For comparison, the relatively closed Paatsalu and South Saaremaa

Table 4. Loadings of seven factors calculated from residual bird numbers when the total number of birds is partialled out. F1, .., F7 denote factors; site clusters are as in Fig. 1

\begin{tabular}{lrrrrrrrrr}
\hline Site & \multicolumn{1}{c|}{ F1 } & \multicolumn{1}{c}{ F2 } & \multicolumn{1}{c}{ F3 } & \multicolumn{1}{c}{ F4 } & \multicolumn{1}{c}{ F5 } & \multicolumn{1}{c}{ F6 } & \multicolumn{1}{c}{ F7 } \\
\hline Hi & $\underline{-0.496}$ & $\underline{-0.731}$ & 0.248 & -0.039 & -0.099 & -0.130 & 0.069 \\
$\mathrm{Ha}$ & 0.036 & 0.194 & -0.288 & -0.376 & -0.367 & -0.053 & $\underline{0.689}$ \\
$\mathrm{Ma}$ & $\underline{0.798}$ & -0.264 & 0.193 & 0.257 & -0.164 & -0.196 & -0.031 \\
$\mathrm{~Pa}$ & -0.023 & 0.019 & -0.048 & 0.151 & -0.217 & $\underline{0.879}$ & -0.171 \\
$\mathrm{ES}$ & -0.249 & $\underline{0.585}$ & $\underline{0.615}$ & 0.189 & -0.121 & -0.200 & -0.053 \\
SS & 0.114 & 0.023 & 0.124 & -0.219 & $\underline{0.855}$ & 0.155 & 0.206 \\
$\mathrm{WS}$ & -0.203 & 0.088 & $\underline{-0.605}$ & $\underline{0.604}$ & 0.177 & -0.250 & -0.044 \\
NS & 0.022 & 0.087 & -0.239 & $\underline{-0.566}$ & -0.065 & -0.204 & $-\underline{0.666}$
\end{tabular}

Note: Underlined dominating loadings correspond to between-clusters exchange systems; the negative sign discriminates the donor from the acceptor site clusters. 


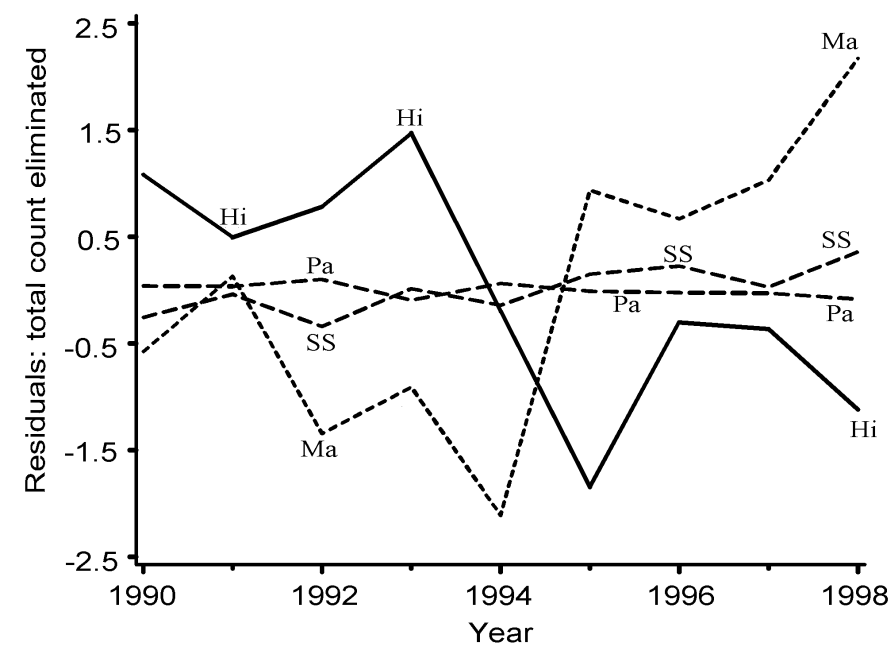

Fig. 5. Hiiumaa (Hi) and Matsalu (Ma) form an exchange system of greylag geese. Paatsalu (Pa) and South Saaremaa (SS) do not participate in this exchange system.

systems are provided on the same graph. The different character of bird number fluctuations can be clearly perceived in these systems.

The dynamics of the factor F1 representing the Hiiumaa-Matsalu system is shown in Fig. 6. A significant linear trend $(P=0.0295)$ can again be detected indicating that the Matsalu site has become more attractive than Hiiumaa.

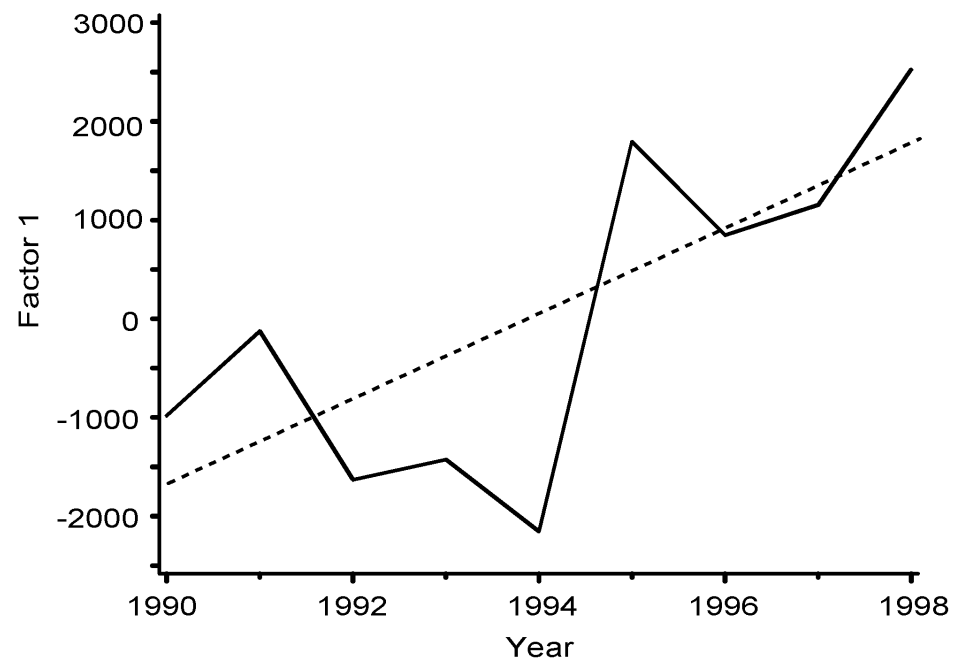

Fig. 6. Factor F1 (see Table 4) shows relocations of graylag geese within the Hiiumaa-Matsalu exchange system during 1990-98. The corresponding linear trend is significant $(P=0.0295)$. 


\section{DISCUSSION AND CONCLUSIONS}

The actual number of staging birds can only be estimated by using sophisticated statistical methods. The method presented in this paper provides on average 1.59 times higher estimates than the documented counts. In 1990-93 the ratio of "estimated number of birds" to "observed number of birds" was 1.81 while in 1994-98 it was 1.42 . Thus, the censuses of the latter period were probably carried out more carefully.

We did not find any overall linear trends in long-term changes in the numbers of autumn staging greylag geese, but there is a significant difference in the linear trends of the separate site clusters (staging areas). This suggests that the preferences of staging areas have changed during the study period. Matsalu Bay has become more important compared to Hiiumaa and Saaremaa in recent years. The main reasons for the relocation of geese seem to be a cumulative effect of increased disturbance, shooting pressure and deficiency of suitable feeding habitats.

It is known that in Hiiumaa there was a relatively high shooting pressure to waterfowl, including the greylag goose, all over the island in the 1990s. During this period a total of 120 to 190 geese were killed annually as a result of hunting, culminating in 1996 (unpublished bag statistics). The counts indicate that the number of staging geese decreased rapidly in the middle of the decade and stabilized at a level of approximately three times lower than at the beginning of the decade (Table 1 and Fig. 2). The effect of shooting on the local population is also illustrated by a decrease in the breeding population in Käina Bay and on the sea islets around Hiiumaa in the middle of the 1990s (Leito \& Leito, 1995; Leito \& Leito, unpublished data). In our opinion shooting had a significant effect on the mortality of the local population as well as an indirect effect on the distribution and relocation of staging geese in Hiiumaa in the 1990s. The effect of hunting on the mortality and distribution of waterfowl, including different goose populations, is a well-known phenomenon and has been treated profoundly in several studies (for reviews, see Ebbinge, 1991; Kalchreuter, 1991).

In addition to the shooting pressure, staging of geese has been strongly affected by lack of suitable feeding habitats due to the decline in agricultural activity in several regions of Estonia in the 1990s. The total area of arable land in Hiiumaa has decreased approximately by $50 \%$ (cereals $80 \%$ ) compared to the total area in the middle of the 1980s (Eesti statistika aastaraamat, 2001, and by personal mapping of agricultural land use in Hiiumaa during the geese censuses). The area under barley, which is the most important food for staging geese, decreased rapidly in the middle of the 1990s. Consequently, the rapid decrease in the numbers of the staging greylag geese corresponds to the reduction of the area of suitable feeding fields, especially those under barley. Compared to Hiiumaa, changes in the feeding conditions of the greylag geese around Matsalu Bay are less significant. The area of arable land has been reduced but several large fields are still being cultivated. The coastal meadows around Matsalu Bay, where geese often feed, have also preserved much better than in Hiiumaa (Leibak \& Lutsar, 1996; Eesti statistika 
aastaraamat, 2001). Thus, different suitable feeding habitats in large areas are available for geese around Matsalu Bay and in its surroundings.

Hunting is banned on the whole territory of Matsalu Nature Reserve, except limited shooting of predators for the regulation of their number. The total area of the nature reserve is $476 \mathrm{~km}^{2}$ and there are several good feeding and roosting sites for geese without any serious disturbances. Therefore, it is understandable why geese prefer Matsalu Bay to other areas with shooting pressure, disturbance and/or limited areas of feeding and roosting sites. Because of the high capacity and quality of feeding and roosting habitats of the greylag goose, Matsalu Bay and its surroundings have been (at least during the 1990s) one of the most important autumn staging sites for the greylag goose in the Baltic Basin (Madsen et al., 1999). It seems to be a key area for geese, regulating the number and distribution of birds also in other staging areas in western Estonia.

Geese from Matsalu Bay are in close contact with geese from Hiiumaa. Besides the Hiiumaa-Matsalu exchange system, other less clear systems exist. In addition, Matsalu and Hiiumaa have a parallel connection with East Saaremaa, forming a three-site exchange system for geese. More or less clear connections also exist between East and West Saaremaa as well as North and West Saaremaa, but Paatsalu and South Saaremaa are relatively isolated staging areas (see Table 4 and Fig. 5). It is difficult to explain all the connections because we do not know the actual population structure and origin of staging geese.

There is a great difference whether birds have gathered incidentally or have had close contacts to and earlier memories of the staging sites. The greylag goose is known to have closed and open groups (Hudec \& Rooth, 1970; Rutschke, 1982). A closed group is a pair or a family where birds have tight relationships and where the exchange of members between different groups is almost excluded. An open group is, for example, a migratory flock, a feeding flock, or a night roosting group. In the barnacle goose, Branta leucopsis, seven different aggregation levels have been described in the spring migration period: a pair or an individual, a family, an elementary flock, an assembly (including a migratory flock, a feeding flock, and a roosting flock), an association of assemblies, a local population, and a total population (Leito, 1996b). This suggests that the greylag goose forms an aggregated whole of birds and not a random complex in Estonia in September. It is possible to go with the statistical analysis of the dynamic distribution of staging migratory birds even deeper, considering the corresponding networks (Möls et al., 2002).

Our results suggest that the distribution of geese may be affected besides the feeding and resting conditions also by the experiences and traditions of different bird groups. Geese in some staging areas may be more resident than geese of other sites because of different site-fidelity. An interesting conclusion from our study is that a large part of the birds inhabiting the sites of the Hiiumaa-Matsalu exchange system are less committed to their resting places than those of the other systems studied.

Consequently, although we know the general situation and the changes in the numbers and distribution of the autumn staging greylag goose in western Estonia 
quite well, more research is needed to understand the importance of different factors affecting the staging of geese in different situations. Thorough research of the effect of shooting as well as of the feeding and roosting conditions in different staging sites has to be carried out. Although these problems are very complicated, such research is necessary for the management of the population, provision of arguments concerning bag limits, and protection of the greylag goose and its habitats.

\section{ACKNOWLEDGEMENTS}

We would like to express our gratitude to all the people who contributed to the mid-September counts of the greylag goose in Estonia over the 1990-98 period. We thank the volunteers from Läänemaa and Saaremaa bird clubs and the Estonian Ornithological Society, as well as the staff of Matsalu Nature Reserve and Vilsandi Nature Park. Financial resources for the censuses and studies were provided by the Estonian Ministry of the Environment and the Estonian Environmental Foundation. Since 1994 censuses of autumn staging greylag goose have been also a part of the national bird-monitoring programme, financed from the state budget.

\section{REFERENCES}

Ebbinge, B. S. 1991. The impact of hunting on mortality rates and spatial distribution of geese wintering in the Western Palearctic. Ardea, 79(2), 197-210.

Hudec, K. \& Rooth, J. 1970. Die Graugans (Anser anser). Die Neue-Brehmbücherei. Ziemser Verlag, Lutherstadt-Wittenberg.

Eesti statistika aastaraamat 2001. Statistical Yearbook of Estonia 2001. Tallinn.

Kalchreuter, H. 1991. On impact of hunting on goose populations - a literature search. Ardea, 79(2), 211-216.

Kumari, E. 1938. Metshaned. Loodusevaatleja, 1, 2-5.

Kumari, E. 1984. Recent developments in the Greylag Goose populations in the eastern part of the Baltic basin. Ardeola, 31, 27-32.

Leibak, E., Lilleleht, V. \& Veroman, H. (eds.) 1994. Birds of Estonia. Status, Distribution and Numbers. Estonian Academy Publishers, Tallinn.

Leibak, E. \& Lutsar, L. (eds.) 1996. Eesti ranna- ja luhaniidud. Estonian Coastal and Floodplain Meadows. Kirjameeste Kirjastus, Tallinn.

Leito, A. 1994. Sügisrändel peatuvate hallhanede loendustulemustest Eestis. Hirundo, 7(2), 46-51.

Leito, A. 1996a. The status, number and distribution of geese (Anser sp., Branta sp.) in Estonia. Gibier Faune Sauvage, Game Wildl., 13, 367-379.

Leito, A. 1996b. The Barnacle Goose in Estonia. Estonia Maritima, 1, 1-103.

Leito, A. \& Leito, T. 1995. Hiiumaa linnustik. Bird fauna of Hiiumaa. Pirrujaak, 4. Biosfääri Kaitseala Hiiumaa Keskus, Kärdla.

Lõhmus, A., Kuresoo, A., Leibak, E., Leito, A., Lilleleht, V., Kose, M., Leivits, A., Luigujõe, L. \& Sellis, U. 1999. Eesti lindude staatus, pesitsusaegne ja talvine arvukus. Hirundo, 11(2), 63-83.

Madsen, J., Cracknell, G. \& Fox, A. D. (eds.) 1999. Goose Populations of the Western Palearctic. A Review of Status and Distribution. Wetlands Int. Publ., No. 48. Wetlands International, The Netherlands; National Environmental Research Institute, Rönde, Denmark. 
Möls, T. \& Paal, J. 1998. Structural indices for plant metapopulation studies: an example using a Vaccinum vitis-idaea L. metapopulation. Baltic Forestry, 4(2), 21-30.

Möls, T., Leito, A. \& Tuul, M. 2002. Staging sites of migratory birds: an example of 1990-1998 greylag goose data analysis. In Theory of Webs and Networks, pp. 39-46. Schola Biotheoretica, 28. Sulemees Publishers, Tartu.

Paakspuu, V. 1974. The Greylag Goose in Estonia. In Estonian Wetlands and Their Life (Kumari, E., ed.), pp. 73-94. Tallinn.

Rutschke, E. 1982. Stability and dynamics in the social structure of the Greylag Goose (Anser anser). Aquila, 89, 39-55.

SAS Institute Inc. 1996. SAS/STAT Software: Changes and Enhancements through Release 6.11. SAS Institute Inc., Cary, NC.

Scott, D. A. \& Rose, P. M. 1996. Atlas of Anatidae Populations in Africa and Western Eurasia. Wetlands Int. Publ., No. 41. Wetlands International, Wageningen, The Netherlands.

\section{Sügisrändel peatuvate hallhanede arvukus ja levik Eestis aastail 1990-1998}

\section{Aivar Leito, Tõnu Möls, Eve Mägi ja Taivo Kastepõld}

Kasutades uut statistilist lähenemist, uuriti sügisrändel peatuvate hallhanede (Anser anser) arvukust ja levikut Eestis aastail 1990-1998. Analüüs näitas, et peatuvate hallhanede arvukusel Eestis tervikuna puudub vaadeldaval perioodil statistiliselt oluline kindlasuunaline lineaarne trend, kuid olulised muutused on toimunud eri peatumispiirkondade eelistustes: linnud on peatumispiirkondade vahel ümber paiknenud. Kõige enam on suurenenud Matsalu eelistatus ja vähenenud Hiiumaa osatähtsus. Peakomponentanalüüsiga õnnestus hinnata lindude ümberpaiknemise mustrit uurimisalal ja välja selgitada omavahel seotud peatumispiirkonnad. 